ISSN (print) 0867-2008 / ISSN (online) 2391-7512

DOI: http://dx.doi.org/10.12775/OM.2021.013

\author{
Anthony LutTrell* \\ Emeritus \\ 20 Richmond Place \\ Bath BA1 5PZ \\ United Kingdom \\ margaretluttrell@gmail.com
}

\title{
A HOSPITALLER DESPROPRIAMENTUM: DUBROVNIK 1396
}

\section{KEYWORDS}

history; the Middle Ages; military orders; Hospitallers; Dalmatia; Dubrovnik; conflicts; late crusades

\begin{abstract}
A Hospitaller, being vowed to poverty, could not make a will but might dispose of goods he held by making a despropriamentum. Written examples are rare but Fr. Barras de Barras made such bequests at Dubrovnik in I 396; his wealth was notably limited. He fell ill while King Sigismund of Hungary, returning from defeat by the Turks at Nikopolis on the Danube where the Hospitallers rescued him, had stopped at Dubrovnik.
\end{abstract}

$\mathrm{F}$ ully-professed members of the military-religious Order of Saint John of Jerusalem took vows of poverty, chastity and obedience. The vow of poverty meant that technically they owned no property which they could bequeath in a will, though in reality brethren needed to travel, to acquire armour and clothing, and generally to move in secular society. All such wealth, in some cases considerable, was supposed on a Hospitaller's death to revert to the Order as his spolia, concerning which there was much statutory legislation and many disputes as to who should receive the deceased's goods. A Hospitaller's possessions might be very modest or might include large sums of money, extensive property, houses, estates and even slaves, together with a wide variety of plate and domestic items.

${ }^{*}$ No ORCID-number. 
A statute passed or confirmed in 1262 decreed that in the central Convent, then in Acre, a critically ill frater had to reveal his possessions and assets. ${ }^{1}$ However, brethren could, with superior licence, make a despropriamentum through which they could list special legacies to pay their servants, settle debts and so forth. There was seldom reason for such written texts to survive, since the case of a Hospitaller dying in a place in which there was no Hospitaller community and in consequence a need for a written document was likely to be unusual. It did, however, occur at Dubrovnik in 1396.

The Hospitaller Fr. Barras de Barras very probably came from the Provençal family which provided two leading Hospitaller Priors of Saint-Gilles in the thirteenth century. ${ }^{2}$ In 1330 a Fr. Barras de Barras was a former Commander of Saint-Pierre-Avez in Provence east of the Rhône, ${ }^{3}$ and in 1338 Barras, Ferran and Guillaume de Barras were noble donats of the Hospital. ${ }^{4}$ A Fr. Barras de Barras went to Rhodes with horses and armour at some point between I 365 and I 374 ; then travelled to the Priory of Hungary with Fr. Raymond de Beaumont, Prior of Hungary between $\mathrm{I} 374$ about I 384 ; and was thereafter resident in the West, probably in Provence. From Avignon on 5 February 1392 the Master Fr. Juan Fernández de Heredia wrote to Rhodes instructing that Fr. Barras, who was returning to Rhodes, be granted seniority there. ${ }^{5}$ He was on Rhodes in I 396 but died at Dubrovnik on or after 30 December I 396, possibly early in the following month.

I Jochen Burgtorf, “The Order of the Hospital's High Dignitaries and their Claims on the Inheritance of Deceased Brethren - regulations and conflicts," in Autour de la Premiere Croisade, ed. Michel Balard (Paris: Publications de la Sorbonne, 1996), 255-265; Anthony Luttrell, "The Finances of the Commander in the Hospital after 1 306," in La Commanderie: Institution des Ordres Militaires dans l'Occident médiéval, eds. Anthony Luttrell and León Pressouyre (Paris: Comité des travaux historiques et scientifiques, Ministère de l'Éducation nationale Ministère de la Recherche, 2002), 277-283; Pierre Bonneaud, "Les Hospitaliers de Rhodes au regard de leur Voeu de Pauvreté au XV' siècle (1420-I 480)," Imago Temporis: Medium Aevum 7 (201 3 ): $538-559$.

2 Anthony Luttrell, "Les femmes hospitalières en France méridionale," Cabiers de Fanjeaux $4 \mathrm{I}$ (2006): 105.

3 Anthony Luttrell and Anne-Marie Legras, "Les hospitaliers autour de Gap: une Enquête de I 330 ," Mélanges de l'École française de Rome: Moyen Âge - Temps Modernes 90 (1 978): 628.

4 Benoît Beaucage, Visites générales des commanderies de l'Ordre des Hospitaliers dépendantes du Grand Prieuré de Saint-Gilles (1338) (Aix-en-Provence: Université de Provence, 1982), 200, 382.

5 Malta, National Library of Malta, Archives of the Order of Saint John of Jerusalem, Cod. 325 , f. 67v-68 (6 Iv-62); background in Zsolt Hunyadi, "The Military Activity of the Hospitallers in the Medieval Kingdom of Hungary (Thirteenth to Fourteenth Centuries)," in The Hospitallers, the Mediterranean and Europe: Festschrift for Anthony Luttrell, ed. Karl Borchardt, Nikolas Jaspert, and Helen J. Nicholson (Aldershot: Ashgate, 2007), 201; id., The Hospitallers in the 
Fr. Barras' despropiamentum was entered in the town's register of wills at Dubrovnik on 30 December 1396 under the heading Testamentum Fratris Baraxij ordinis Templariorum de Rodo.$^{6}$ Before the rector of the city and various witnesses his possessions were recorded in the Venetian language used there. The sick man listed his "harness", which may have included some armour or even a horse, and all his crossbows and his bed, all of which were on Rhodes. He had with him 190 gold ducats and four silver cups. He left 90 ducats to reconcile his soul, presumably in memorial masses. He also had with him two silver belts, one large and one small, and a gold piece worth about 17 ducats. Fr. Johan de Richtenberg owed him 20 ducats. With him were his coat of camelot and a small robe which he left to "distribute for the love of God." He also had a galley bed which his left to his valet, a steel body plate, and three rings. All these items he left in the hands of the treasurers at Dubrovnik to be sent to Rhodes. He added to the list a piece of silver worth 16 ducats. An entry in the margin of the same folio in the register of wills recorded that on 9 September 1397 Fr. Antonio de Rivara formally took possession of Fr. Barras' goods and monies. His career and seniority brought Fr. Barras no office or fixed income. He was evidently a knight brother in possession of his weapons, a valet and some personal items, yet his wealth was very moderate at less than 200 ducats.

Fr. Barras, who left his belongings on Rhodes, may have been at Dubrovnik in December 1396 on his way Westwards from Rhodes on some mission, possibly to Hungary where he had had some experience. The Master of the Hospital Fr. Philibert de Naillac, elected on Rhodes on 6 May I 396,7 had recently been closely involved with King Sigismund of Hungary following the defeat of the Latin crusade at Nikopolis on the Danube, and Fr. Barras could have been travelling to oversee some arrangement for the Hospitallers in Hungary. It was also possible that Naillac had taken Fr. Barras, with his Hungarian background, to Nikopolis. Fr. Barras may have been travelling with Sigismund since his despropriamentum was drawn up at Dubrovnik on 30 December, the day or the day after Sigismund, who spent some days at Dubrovnik, left on his long journey back from Nikopolis to Hungary. ${ }^{8}$ The Hospitaller Master had travelled with one or more galleys from

Medieval Kingdom of Hungary c.1150-1387 (Budapest: Magyar Egyháztörténeti Enciklopédia Munkaközösség. Department of Medieval Studies at Central European University, 2010), 6 I.

6 Dubrovnik, State Archives, Testamenta VIII, f. gov.

7 Anthony Luttrell and Elizabeth A. Zachariadou, Sources for Turkish History in the Hospitallers' Rhodian Archive 1389-1422 (Athens: National Hellenic Research Foundation, 2008), 45 n. 87.

8 The precise date is unclear: Ciro Truhelka, "Chronikalische Notizen im Liber Reformationum des Archivs in Ragusa," Wissenschaftliche Mitteilungen aus Bosnien und der Herzogovina 
Rhodes to Nikopolis where, probably on 25 September $1396,{ }^{9}$ he and various Hospitallers took part in the battle against the Ottoman forces of the Sultan Bayezid. Johannes Schiltberger, who was there, later described how Sigismund and a few companions escaped down the Danube on Naillac's vessel. ${ }^{10}$ Jean Froissart, who was not present but knew people who were, said that Sigismund escaped on a petite barge of Naillac, i I. ${ }^{11}$ Ibn al-Jazarī, who was at the battle, said that Sigismund escaped by ship with approximately fifty persons. ${ }^{12}$ Sigismund seems later to have transferred, perhaps in the Bosphoros, to a Venetian galley. ${ }^{13}$

Sigismund had been at Constantinople for some time when on i I November he wrote to Naillac claiming to have reached the city just in time to prevent it falling to Bayezid. ${ }^{14}$ Since the sultan had been compelled to lift his blockade of Constantinople to march to Nikopolis where his troops suffered considerable losses, it was arguable that the Nikopolis crusade had, despite its disastrous conclusion, actually saved Constantinople. ${ }^{15}$ Sigismund's letter stated that the Hospital's Admiral, Fr. Palamedo di Giovanni, ${ }^{16}$ would explain matters to Naillac; the Admiral may have been at Nikopolis and may have stayed in Constantinople in order to

I I ( 1909 ): 373. Kenneth Setton, The Papacy and the Levant (I204-I57I) (Philadelphia: American Philosophical Society, 1976), 356-357.

9 Ibn al-Jazarī, who was there, gave 25 September: Ilker Evrim Binbaş, "A Damascene Eyewitness to the Battle of Nicopolis: Shams al-Dīn Ibn al-Jazarī (d. 833/ 1429)," in Contact and conflict in Frankish Greece and the Aegean, I204 - 1453: crusade, religion and trade between Latins, Greeks and Turks, ed. Nikolaos Chrissis and Mike Carr (Farnham: Ashgate, 2014), I 70. Luttrell and Zachariadou, Sources for Turkish History, 46-47 n. 90, propose 24 September when the English Hospitaller Fr. John Raddington apparently died, but he could have died one day before the battle.

10 Hans Schiltbergers Reise in die Heidenschaft, ed. Rose Grässel (Hamburg: Claasen \& Goverts, I 947), 25.

i1 Jean Froissart, Oeuvres, vol. I 5, ed. Kervyn de Lettenhove (Brussels: V. Devaux, I 87 I), 317.

12 Binbaş, "A Damascene Eyewitness," I 69.

13 Luttrell and Zachariadou, Sources for Turkish History, 46 n. 89.

${ }_{14}$ Text and discussion in John W. Barker, Manuel II Palaeologus (139I-1425): A Study in Late Byzantine Statesmanship (New Brunswick: Rutgers University Press, 1969), 482-485.

is As suggested in Luttrell and Zachariadou, Sources for Turkish History, 48-49.

${ }_{16}$ On Fr. Palamedo, Joseph Delaville le Roulx, Les Hospitaliers à Rhodes jusqu’à la mort de Philibert de Naillac (1310-I42I) (Paris: Ernest Leroux, I 91 3), 2 I 3 n. I. Barker, Manuel II Palaeologus, 483 , mistakenly gives admiratus as "admirable". Further observations in id., "Byzantium and the Hospitallers, I 306 - I 42 I," in Bisanzio, Venezia e il mondo franco-greco (XIII-XV secolo), ed. Chryssa Maltezou and Peter Schreiner (Venice: Istituto Ellenico di Studi Bizantini e Postbizantini, 2002), 5 I-52, but I I November was scarcely "a little over two weeks after" 25 September. Naillac was elected on 5 May and not during the Nikopolis campaign, and was back on Rhodes by I 2 January 1397 at latest: Luttrell and Zachariadou, Sources for Turkish History, 45 n. 87, 47 n. 93. Sigismund did not go to Rhodes as often claimed. 
deal with developments there. ${ }^{17}$ Sigismund's letter called upon the Master to provide galleys, together with those of the Venetians, Genoese and Greeks, for the defence of the Byzantine capital. Fr. Barras could have been at Nikopolis and later in Constantinople with Sigismund, and could then have travelled with him to Dubrovnik. Since the Hospital's Priory of Hungary had at that time fallen into the hands of seculars, some of whom rebelled against Sigismund, ${ }^{18}$ Fr. Barras conceivably, but hypothetically, died en route while on a mission to Hungary.

\section{SOURCE TEXT ${ }^{19}$}

\section{Dubrounik, 30 December 1396}

In nomine Christi amen. Io Frar Baras de Baraso faço lo mio despropriamento. Primamente el mio arnese el qual e in Rode, tutte le mie balestre son in Rode, tutel mio leto si e in Rode guarnito. Agio cum mi duc[ati] centononanta doro. Agio cum mi iiij taçe dargento. De quisti Clxxxx. duc[ati] agio retignudo duc[ati] lxxxx per aconçar l’anima mia. Agio cum mi zenture ij dargento j. gra[n]de laltra piçulla. Agio cum mi .j. peça doro, che val cercha duc[ati] xvij. Frar Zuan de Ritterberch de me dar duc[ati] xx. Agio cum mi pellanda .j. de zamiloto inforada, de grixa de gropa. Agio altra roba minuda la qual lasso a partir per lamor de dio. Letto .j. de galia lasso alo mio vayletto. Agio cum mi una panciera daçaro. Agio anelli iij. in soffilli, et altro stopanco, el terço sie granata intayata. ${ }^{20 a}$ Tutte queste conse recommando in le man deli thesaurierj de Ragusa pregando lor che li debia mandar in Rode. Agio cum mi una peça dargento, val[ente] duc[ati] xvj. Hoc autem testamentum nullo testimonio rumpi possit.

\section{PRIMARY SOURCES:}

Dubrovnik. State Archives, Testamenta VIII, f. 9 ov.

17 Assuming that Naillac reached or passed by Constantinople before Sigismund's arrival there.

18 Zsolt Hunyadi, "The Hospitallers in the Kingdom of Hungary: Commanderies, Personnel, and a Particular Activity up to c. I 400," in The Crusades and the Military Orders: Expanding the Frontiers of Medieval Latin Christianity, ed. Zsolt Hunyadi and Jozsef Laszlovszky (Budapest: Central European University Press, 2001 ), 262-263; Anthony Luttrell, Studies on the Hospitallers after 1306: Rhodes and the West (Aldershot: Ashgate, 2007), 276-277.

19 Dubrovnik, State Archives, Testamenta VIII, f. gov.

${ }^{20^{a}}$ Rings of soffilli, possibly sapphire; stopanco, possibly topazio or topaz; and garnet. 
Malta. National Library of Malta. Archives of the Order of Saint John of Jerusalem, Cod. 325, f. 67v-68r (6rv-62r).

Froissart, Jean. Oeuvres. Edited by Kervyn de Lettenhove. Vol. XV. Brussels: V. Devaux, I $87 \mathrm{I}$.

Hans Schiltbergers Reise in die Heidenschaft. Edited by Rose Grässel. Hamburg: Claasen \& Goverts, 1947.

Schiltberger, Johannes. Als Sklave im Osmanischen Reich und bei den Tataren, 1394-1427. Edited by Ulrich Schlemmer. Stuttgart: Thienemann, I 983.

\section{SeCondary SOURCES:}

Barker, John W. "Byzantium and the Hospitallers, I 306-I 42 I." In Bisanzio, Venezia e il mondo franco-greco (XIII-XV secolo), edited by Chryssa Maltezou and Peter Schreiner, 4I-64. Venice: Istituto Ellenico di Studi Bizantini e Postbizantini, 2002.

Barker, John W. Manuel II Palaeologus (I39I-I425): a Study in Late Byzantine Statesmanship. New Brunswick: Rutgers University Press, 1969.

Beaucage, Benoît, Visites générales des commanderies de l'Ordre des Hospitaliers dépendantes du Grand Prieuré de Saint-Gilles (1338). Aix-en-Provence: Université de Provence, I 982 .

Binbaş, Ilker Evrim. "A Damascene Eyewitness to the Battle of Nicopolis: Shams al-Dìn Ibn al-Jazarī (d. 833/ I 429)." In Contact and conflict in Frankish Greece and the Aegean, I204 - I453: crusade, religion and trade between Latins, Greeks and Turks, edited by Nikolaos Chrissis and Mike Carr, I 53-i 76. Farnham: Ashgate, 2014.

Bonneaud, Pierre. "Les Hospitaliers de Rhodes au regard de leur Voeu de Pauvreté au XV siècle (1 420-I 480)." Imago Temporis: Medium Aevum 7 (2013): 538-559.

Burgtorf, Jochen. "The Order of the Hospital's High Dignitaries and their Claims on the Inheritance of Deceased Brethren - regulations and conflicts." In Autour de la Première Croisade, edited by Michel Balard, 255-265. Paris: Publications de la Sorbonne, I 996.

Delaville le Roulx, Joseph. Les Hospitaliers a Rhodes jusqu'a la mort de Philibert de Naillac (I3IO-I42I). Paris: Ernest Leroux, I 9 I 3.

Hunyadi, Zsolt. "The Hospitallers in the Kingdom of Hungary: Commanderies, Personnel, and a Particular Activity up to c. I 400." In The Crusades and the Military Orders: Expanding the Frontiers of Medieval Latin Christianity, edited by Zsolt Hunyadi and Jozsef Laszlovszky, 253-268. Budapest: Central European University Press, $200 \mathrm{I}$.

Hunyadi, Zsolt. The Hospitallers in the Medieval Kingdom of Hungary c. II50-1387. Budapest: Magyar Egyháztörténeti Enciklopédia Munkaközösség. Department of Medieval Studies at Central European University, 20 I o.

Hunyadi, Zsolt. "The Military Activity of the Hospitallers in the Medieval Kingdom of Hungary (Thirteenth to Fourteenth Centuries)." In The Hospitallers, the Mediterranean and Europe: Festschrift for Anthony Luttrell, edited by Karl Borchardt, Nikolas Jaspert, and Helen J. Nicholson, I 93-203. Aldershot: Ashgate, 2007.

Luttrell, Anthony. "Les femmes hospitalières en France méridionale." Cabiers de Fanjeaux 4I (2006): IOI-I I 4 . 
Luttrell, Anthony. Studies on the Hospitallers after 1306: Rhodes and the West. Aldershot: Ashgate, 2007.

Luttrell, Anthony. "The Finances of the Commander in the Hospital after I 306 ." In La Commanderie: Institution des Ordres Militaires dans l'Occident médiéval, edited by Anthony Luttrell and León Pressouyre, 277-283. Paris: Comité des travaux historiques et scientifiques, Ministère de l'Éducation nationale Ministère de la Recherche, 2002.

Luttrell, Anthony, and Anne-Marie Legras. "Les hospitaliers autour de Gap: une Enquête de I 330." Mélanges de l'École française de Rome: Moyen Âge - Temps Modernes 90 (1978): 627-642.

Luttrell, Anthony, and Elizabeth A. Zachariadou. Sources for Turkish History in the Hospitallers' Rhodian Archive 1389-1422. Athens: National Hellenic Research Foundation, 2008.

Setton, Kenneth. The Papacy and the Levant (I204-I57I). Volume I. Philadelphia: American Philosophical Society, 1976.

Truhelka, Ciro. "Chronikalische Notizen im Liber Reformationum des Archivs in Ragusa." Wissenschaftliche Mitteilungen aus Bosnien und der Herzogovina I I ( 909 ): 369-374. 